\title{
The impact of $A C E$ gene polymorphism on the incidence and phenotype of sarcoidosis in rural and urban settings
}

\author{
Robert Kieszko ${ }^{1}$, Paweł Krawczyk ${ }^{1}$, Tomasz Powrózek ${ }^{1}$, Aneta Szudy-Szczyrek ${ }^{2}$, Michał Szczyrek ${ }^{1,3}$, \\ Iwona Homa ${ }^{1}$, Jadwiga Daniluk ${ }^{3,4}$, Janusz Milanowski ${ }^{1}$
}

\author{
${ }^{1}$ Department of Pneumonology, Oncology and Allergology, Medical University \\ of Lublin, Lublin, Poland \\ ${ }^{2}$ Chair and Department of Haematooncology and Bone Marrow Transplantation, \\ Medical University of Lublin, Lublin, Poland \\ ${ }^{3}$ Chair of Internal Medicine and Department of Internal Medicine in Nursing, \\ Medical University of Lublin, Lublin, Poland \\ ${ }^{4}$ Department of Health, Pope John Paul II State School of Higher Education, \\ Biala Podlaska, Poland
}

Submitted: 25 September 2014

Accepted: 26 December 2014

Arch Med Sci 2016; 12, 6: 1263-1272

DOI: 10.5114/aoms.2015.48966

Copyright (C) 2015 Termedia \& Banach

\author{
Corresponding author: \\ Michał Szczyrek MD \\ Department \\ of Pneumonology, \\ Oncology and Allergology \\ Medical University of Lublin \\ 8 Jaczewskiego St \\ 20-954 Lublin, Poland \\ Phone: +48 668045853 \\ E-mail: \\ mszczyrek@yahoo.co.uk
}

\begin{abstract}
Introduction: Sarcoidosis is a multisystem granulomatous disease of unknown etiology. Current theory on the etiology of this disease involves participation of genetic factors and unknown antigens present in the patients' environment. The aim of the study was to evaluate the prevalence of different polymorphic forms of the ACE gene in healthy individuals and sarcoidosis patients, and to estimate the risk of sarcoidosis in carriers of different ACE genotypes living in rural and urban settings.

Material and methods: The study group included 180 patients with pulmonary sarcoidosis. Assessment of the disease was based on clinical features, laboratory and imaging examinations, as well as bronchoscopy with bronchoalveolar lavage (BAL). ACE gene polymorphism was examined in DNA isolated from peripheral blood or BAL fluid (BALF) leukocytes.

Results: Incidence of sarcoidosis was not influenced by gender, age or place of residence of the patients. There were no differences in the frequency of particular genotypes in patients with sarcoidosis and in healthy individuals. The risk of disease did not depend on the ACE gene polymorphism. There were no differences in the frequencies of the different genotypes and alleles of the ACE gene in patients with sarcoidosis divided by gender, age and place of residence or by clinical manifestation of sarcoidosis.

Conclusions: Our results do not support the previous concept which suggested a higher incidence of sarcoidosis in individuals living in rural areas and in carriers of selected ACE genotypes. It is possible that this is related to the changing environment of rural areas, increasing urbanization and pollution.
\end{abstract}

Key words: sarcoidosis, ACE gene, polymorphism, T lymphocytes, environment.

\section{Introduction}

Sarcoidosis is a multisystem granulomatous disease of unknown etiology. The lesions may develop in any organ, but in the vast ma- 
jority (approximately 90\%) of patients they can be found in pulmonary and mediastinal lymph nodes, with accompanying changes in lung tissue. It occurs in people of all ages and races, most often before 50 years of age, with peak incidence between 20 and 39. Women are affected slightly more often than men. Incidence of sarcoidosis varies between ethnic groups. The highest annual incidence is recorded in the Scandinavian countries, with about 50 cases per 100000 residents. In Poland, the incidence is estimated at around 10 per $100000[1,2]$.

Current theory on the etiology of the disease involves participation of genetic factors and an unknown antigens present in the patients' environment. Hypothetic pathogenetic factors of sarcoidosis include bacteria and viruses, as well as organic particulates, dust, gases, and air pollution. There is a correlation between incidence and employment in agriculture, and in particular exposure to insecticides, molds and working on bird farms. Sarcoidosis is also more common among employees of car factories and people living in homes with central heating [3].

The importance of genetic background in sarcoidosis is demonstrated by ethnic diversity, familial occurrence of disease, and susceptibility to other granulomatous diseases. Incidence rate and clinical presentation of sarcoidosis in various ethnic groups are closely linked to specific histocompatibility antigens (HLA) class I and II. The development of granulomas is also affected by the polymorphisms of genes responsible for the synthesis of cytokines, chemokines, and costimulatory molecules. Interestingly, these molecules and gene polymorphisms are also involved in pathogenesis of asthma, sleep apnea, idiopathic hypertension and cardiovascular diseases $[4,5]$. These include TAP1, TAP2, TNF- $\alpha, T G F-\beta, I L-1$, CCR2, EGF, CD14, TLR4, TLR9, ACE, and many other genes [6-8]. Researchers have also investigated associations of gene polymorphisms with allergy or chronic inflammation in the context of exposure to different antigens in rural and urban areas [9].

The role of $A C E$ gene polymorphism in the pathogenesis of sarcoidosis is currently at the center of interest of scientists. Angiotensin-converting enzyme I is responsible for the conversion of angiotensin I to II and inactivates the bradykinin pathway in the kallikrein-kininogen system $[10,11]$. Angiotensin II is a vasoconstrictor, and activates renin angiotensin system (RAS) molecules. In addition, angiotensin II is a potential pro-inflammatory agent which stimulates the immune response [12]. It activates pro-inflammatory cells, monocytes, macrophages and epithelial cells. There is a correlation between the number of sarcoidal granu- lomas and ACE serum level. A high level of serum ACE is a marker of disease activity $[13,14]$.

The ACE gene is located on the long arm of chromosome 17 (17q23). The most important polymorphism of the gene involves an insertion of $287 \mathrm{bp}$ in intron 16 [13]. Therefore, there are three genotypes of the ACE gene: I/I, I/D, D/D. D/D genotype is associated with about 2-fold higher concentration of ACE in serum and tissues and is closely associated with the risk of spontaneous hypertension, myocardial infarction and heart failure $[14,15]$. Previous studies on the role of $A C E$ gene polymorphism in the pathogenesis of sarcoidosis are controversial, but it seems that it may be related to the clinical course of the disease.

The aim of the study was to evaluate the prevalence of different polymorphic forms of the ACE gene in healthy individuals and sarcoidosis patients and to estimate the risk of sarcoidosis in patients with different $A C E$ genotypes living in different (rural and urban) settings. An attempt was also made to examine the impact of $A C E$ gene polymorphism on the clinical manifestation of sarcoidosis, with particular emphasis on the occurrence of an acute form of the disease and the degree of activation of the immune system in the respiratory tract in the context of demographic differences in the population.

\section{Material and methods}

\section{Study population}

The study group included 180 patients with respiratory sarcoidosis diagnosed and treated in the Department of Pneumonology, Oncology and Allergology, Medical University of Lublin in the years 2002-2010. About 20 patients per year were enrolled in the study. The assessment of the disease was based on clinical features, chest X-ray and computed tomography (CT), lung function tests, abdomen ultrasonography, ophthalmological examination, bronchoscopy with bronchoalveolar lavage (BAL) and routine blood tests. Löfgren syndrome was manifested in 39 patients, and 88 patients showed bilateral hilar lymphadenopathy in chest X-ray and CT examinations. In 92 patients interstitial infiltration with or without hilar lymphadenopathy (radiological stage II or III) was demonstrated. We made a distinction between the self-limiting clinical course (radiographic stage I), and stage II or III with a high probability of disease progression. In 68 patients extrapulmonary lesions were present. Involved organs included liver, spleen, abdominal lymph nodes, skin (lesions other than erythema nodosum), eye, kidneys, salivary glands, and central nervous system. The heart was not affected by the disease in our examined patients. However, in the literature data cardiac involvement in sarcoidosis occurs in 
20-30\% of patients in pathology series. Sarcoidosis of the heart is being increasingly recognized worldwide, but it has non-specific symptoms. Only $5 \%$ of patients with sarcoidosis have clinical manifestations of cardiac disease, and only $40-50 \%$ of patients with cardiac sarcoidosis at autopsy have the correct diagnosis made during their lifetime. Therefore, cardiac sarcoidosis can still be misdiagnosed in our studied group [16].

The control group consisted of 242 healthy volunteers, living in Lublin Voivodeship, matched to the study group in terms of gender, age and place of residence (Table I).

The research project was approved by the Local Bioethics Committee of the Medical University of Lublin (no: KE-0254/142/2010). The study included patients living within the administrative area of Lublin Voivodeship. Place of residence in the country or in the city was determined at the time of diagnosis, based on the patient's history. Patients living in localities without the official city status or city rights, and reporting a history of exposure to dust or pollution related to crop farming and animal husbandry, were assigned to the rural setting. Lublin Voivodeship is an agricultural region, dominated by the cultivation of fruits, berries, and edible legumes (such as peas, beans and broad beans). Lublin Voivodeship is also one of the largest suppliers of ground vegetables, cereals and potatoes. The dominant species of farm animal is swine, but cattle breeding also plays a significant role. Work in agriculture is associated with exposure to biological and chemical components of agricultural dust. Harmful biological factors present in the dust are mainly agricultural microorganisms (Gram-negative bacteria, thermophilic actinomycetes, molds) and endotoxin. The main chemical exposure in agriculture is from plant protection products (pesticides) [17-19].

Lublin voivodeship is not very urbanized $46.4 \%$ of the population lives in cities. Patients living in settlements with municipal rights or city status were classified as residing in the urban setting. To be enrolled in the study they also could not be employed in agriculture [19].

Air pollution in cities includes contamination of natural origin and related to human activity. The main source of air pollution is anthropogenic emissions from industry, households and transport. Most industrialized areas are located in the central belt of the voivodeship and the largest urban centers. The majority of the industrial emissions are produced by the chemical industry, energetics and heating. Monitoring conducted in the years 2000-2007 showed low concentrations of gaseous pollutants, primarily sulfur dioxide, which in the summer in most locations were
Table I. Characteristics of the studied population

\begin{tabular}{|lcc|}
\hline $\begin{array}{l}\text { Studied factor } \\
\begin{array}{l}\text { Gender: } \\
\text { Male }\end{array}\end{array}$ & $\begin{array}{c}\text { Control group } \\
(n=242)\end{array}$ & $\begin{array}{c}\text { Sarcoidosis } \\
\text { patients } \\
(n=180)\end{array}$ \\
\hline Female & $122(50.4)$ & $85(47.2)$ \\
\hline Age [years] & $120(49.6)$ & $95(52.8)$ \\
\hline \begin{tabular}{l} 
Setting: \\
\hline City
\end{tabular} & $55 \pm 13$ & $47 \pm 12$ \\
\hline Rural & $128(52.9)$ & $94(52.2)$ \\
\hline
\end{tabular}

Results presented as $n(\%)$ or median $\pm S D$.

below the limit of quantification. Annual average nitrogen dioxide concentration remained relatively even and did not exceed the permissible level. The main problem of air quality in the region is exceeding the norms for PM10 dust. The results of ozone level measurements showed permissible values [20].

\section{BAL procedure and BALF cell preparation}

Bronchoalveolar lavage fluid (BALF) was obtained by standard lavage of the middle lobe with seven 20 -ml aliquots of pre-warmed sterile $0.9 \%$ saline. The pooled BALF specimen, except for the first bronchial fraction, was carefully mixed, strained through a double layer of nylon gauze and centrifuged to obtain a cell pellet. Cells were washed twice and resuspended with phosphate-buffered saline (PBS).

Flow cytometry technique and monoclonal antibodies (Simultes, Becton Dickinson, USA) were used for immunophenotyping of BALF mononuclear cells. Cells were incubated for $20 \mathrm{~min}$ at room temperature and immediately analyzed in a FACSCalibur flow cytometer (Becton Dickinson, USA). Remaining cells were centrifuged at $400 \times \mathrm{g}$ and stored at $-80^{\circ} \mathrm{C}$ for $A C E$ gene polymorphism analysis.

\section{Assessment of ACE gene I/D polymorphism}

DNA in patients with sarcoidosis was isolated from BALF cells stored at $-80^{\circ} \mathrm{C}$. DNA from healthy individuals was isolated from leukocytes of peripheral blood collected from the antecubital vein into tubes containing EDTA and stored at $-20^{\circ} \mathrm{C}$. DNA was extracted from the collected peripheral blood and BALF samples using proteinase $\mathrm{K}$ digestion according to the manufacturer's protocol. After 20 min of digestion at $56^{\circ} \mathrm{C}$, DNA was eluted using silica columns with an appropriate buffer kit (QIAamp DNA Blood Mini Kit, Qiagen, USA). Purity control and the assessment of quantity of isolated DNA was performed using a BioPhotometer plus 
spectrophotometer with cuvettes equipped with UV/VIS filters (Eppendorf, Germany).

In order to amplify a fragment of intron 16 with the ACE gene, polymerase chain reaction (PCR) was performed, using primers specific for the analyzed fragment - forward: 5'-CTG GAG AGC CAC TCC CAT CCT TCT 3' and reverse: 5'-GAC GTG GCC ATC ACA TTC GTC AGA TC 3', flanking the polymorphic site (insertion/deletion). PCR was performed in a TPersonal thermocycler (Biometra, USA). The PCR product had 190 base pairs (bp) in the presence of allele $D$, and $480 \mathrm{bp}$ in the presence of allele I. DNA separation was performed in $2 \%$ agarose gel with addition of ethidium bromide. After electrophoresis, the DNA bands were visualized with a UV light transilluminator. In the case of homozygous genotypes I/I, and D/D, one band was observed with a length of 481 or 194 bp. However, in cases where the applied PCR product derived from a heterozygote of the I/D genotype, both bands having respectively 481 and 194 bp were observed (Figure 1).

\section{Statistical analysis}

The data are presented as the median \pm standard deviation (SD). Pearson $\chi^{2}$ analysis was used to test the differences between different groups of patients in the distributions of gender, age, place of residence, $A C E$ genotypes and clinical manifestation of sarcoidosis. Fisher's exact test was applied to test for Hardy-Weinberg equilibrium. Differences of the frequencies of the alleles between control and patient subjects as well as between patients with different manifestations of sarcoidosis were tested by logistic regression analysis using the haplotype frequency estimation program (http://ihg.gsf.de). Odds ratio (OR) and associated $95 \%$ confidence interval $(95 \% \mathrm{Cl})$ were calculated. The Mann-Whitney $U$ test was used for the com- parison of unpaired group data. A level of $p<0.05$ was assigned as significant.

\section{Results}

\section{Clinical and immunological characteristics of patients with sarcoidosis}

Sarcoidosis occurred at similar rates in men and women. The incidence of sarcoidosis was not influenced by the age of the patients or their place of residence (urban or rural).

The incidence rate of various radiological stages of sarcoidosis did not depend on gender $\left(\chi^{2}=\right.$ $0.216 ; p=0.642)$, age $\left(\chi^{2}=1.532 ; p=0.216\right)$ or place of residence $\left(\chi^{2}=1.026 ; p=0.311\right)$. Löfgren syndrome was slightly more common in women $(27.1 \%)$ than in men $\left(15.5 \% ; \chi^{2}=3.556 ; p=\right.$ 0.059). However, there was a similar incidence of Löfgren syndrome in patients in both age groups $\left(\chi^{2}=2.562 ; p=0.109\right)$, and among the inhabitants of towns and villages $\left(\chi^{2}=0.449 ; p=0.503\right)$.

Percentages of lymphocytes and macrophages in BALF, percentages of lymphocyte subpopulations and CD4 : CD8 ratio in BALF were similar in men and women, in patients over 47 years of age and younger, and in patients living in urban and rural areas (Table II). The CD4 : CD8 ratio was significantly higher in patients with radiographic stage I sarcoidosis than in patients with signs of fibrosis of the lung parenchyma (Figure 2, Table II). Patients with Löfgren syndrome had a higher percentage of T lymphocytes and CD4+ Th lymphocytes when compared to patients without acute manifestations of sarcoidosis (Figure 3, Table II).

The incidence of the different polymorphic forms of the ACE gene in healthy individuals ( $p=$ $0.158)$ and in patients with sarcoidosis $(p=0.425)$ was in conformity with the Hardy-Weinberg equilibrium. In both groups, heterozygous individuals having both insertion and deletion variants of the

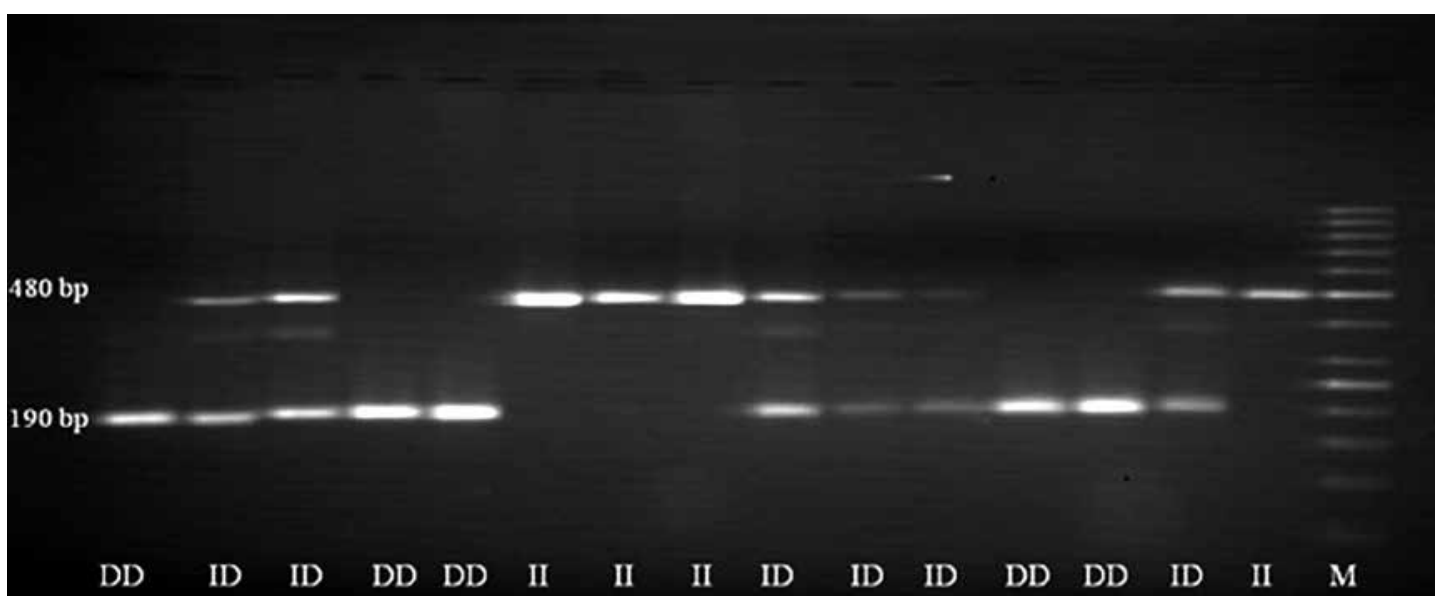

Figure 1. Electrophoretic separation of PCR products containing a polymorphic site I/D of ACE gene. DNA marker - line $M$, homozygotes I/I - line: 1, 8, 9, 10; heterozygotes I/D - line: 2, 5, 6, 7, 13, 14; homozygotes D/D - line: 3, $4,11,12,15$ 
ACE gene were the most common. Homozygous subjects, having two deletion or insertion alleles of the ACE gene, occurred at a frequency of $20 \%$ to $30 \%$ in both groups. Genotype frequencies in healthy subjects were in concordance with results of a study by Camos et al., performed on a Spanish population [21]. There were no differences in the frequency of particular genotypes in patients with sarcoidosis and in healthy subjects. Moreover, the risk of disease did not depend on the ACE gene polymorphism (Table III).

There were no differences in the frequencies of the different genotypes and alleles of the ACE gene in patients with sarcoidosis divided by gender, age and place of residence and presence of extrapulmonary involvement (Table IV). There was no association between the ACE gene polymorphism and clinical manifestation of sarcoidosis: radiographic stage of disease and the occurrence of Löfgren syndrome (Table IV). In patients with different genotypes of the ACE gene we found

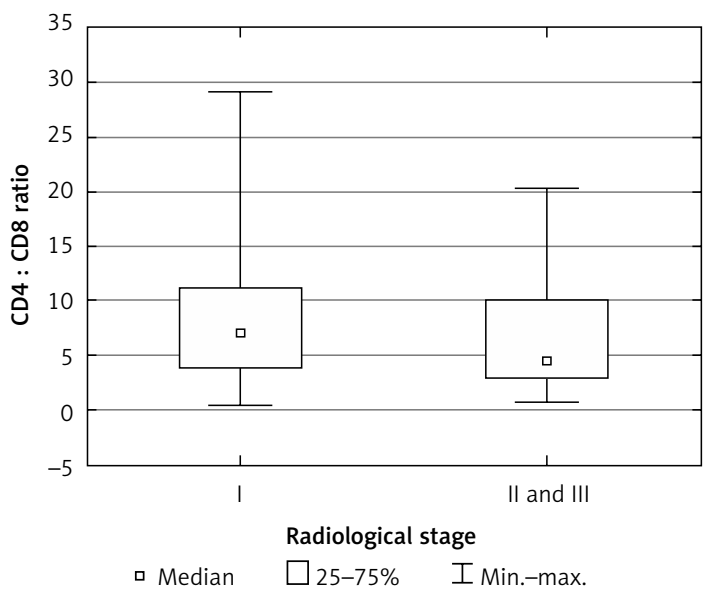

Figure 2. CD4 : CD8 ratio in BALF in sarcoidosis patients with various radiological stages of the disease

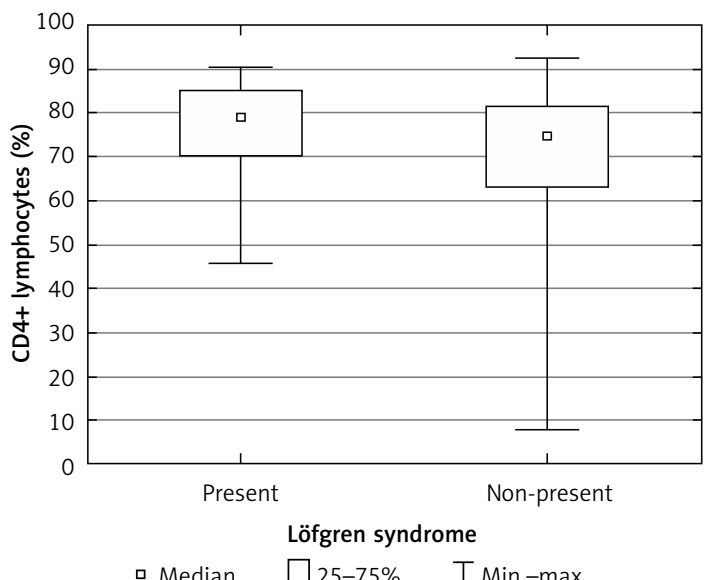

Figure 3. Percentage of CD4+ Th cells in BALF of patients with Löfgren syndrome and without acute manifestations of sarcoidosis

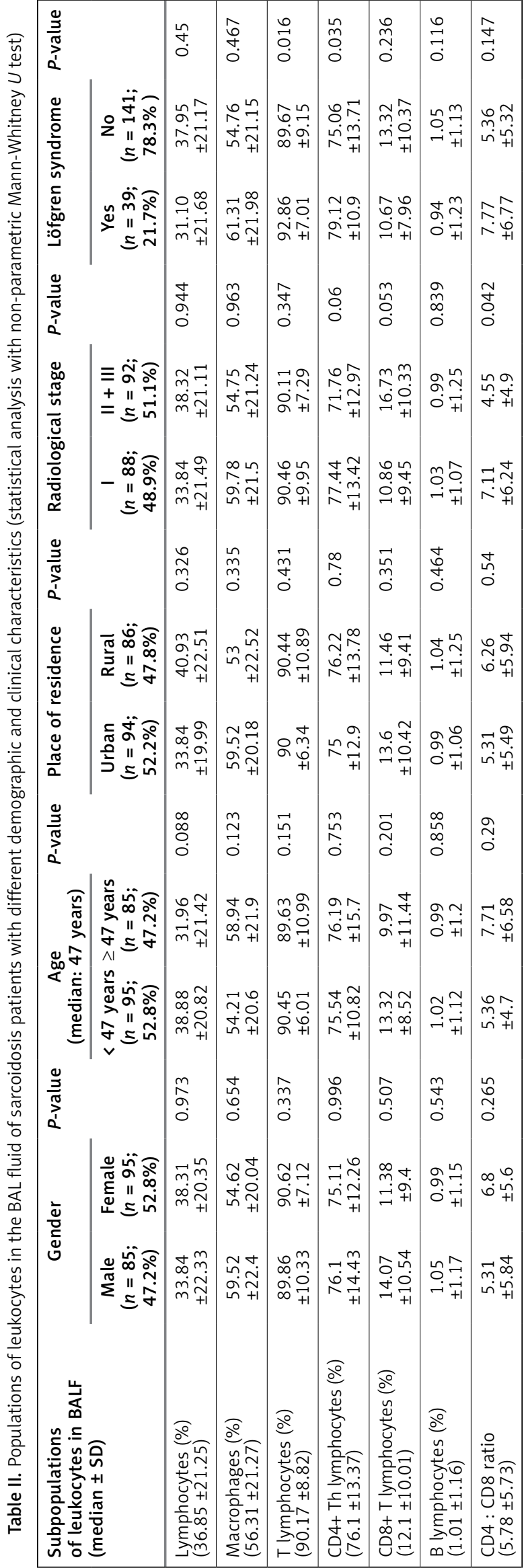


Table III. ACE gene polymorphism and the risk of sarcoidosis

\begin{tabular}{|c|c|c|c|c|}
\hline \multirow{2}{*}{$\begin{array}{l}A C E \text { gene } \\
\text { polymorphism }\end{array}$} & \multicolumn{2}{|c|}{ Studied group } & \multicolumn{2}{|c|}{ Statistical analysis } \\
\hline & $\begin{array}{l}\text { Healthy individuals } \\
\qquad(n=242)\end{array}$ & $\begin{array}{l}\text { Patients with sarcoidosis } \\
\qquad(n=180)\end{array}$ & $\begin{array}{l}p \\
\chi^{2}\end{array}$ & $\begin{array}{c}\text { OR } \\
95 \% \mathrm{Cl}\end{array}$ \\
\hline I/I & $64(26.5 \%)$ & 37 (20.6\%) & \multirow{3}{*}{$\begin{array}{c}0.258 \\
2.71\end{array}$} & \multirow{3}{*}{-} \\
\hline I/D & $110(45.5 \%)$ & 95 (52.8\%) & & \\
\hline $\mathrm{D} / \mathrm{D}$ & $68(28 \%)$ & $48(26.6 \%)$ & & \\
\hline $1 / I+I / D$ & $174(72 \%)$ & $132(73.4 \%)$ & \multirow{2}{*}{$\begin{array}{c}0.744 \\
0.11\end{array}$} & \multirow{2}{*}{$\begin{array}{c}1.075 \\
0.697-1.657\end{array}$} \\
\hline $\mathrm{D} / \mathrm{D}$ & $68(28 \%)$ & $48(26.6 \%)$ & & \\
\hline$D / D+I / D$ & $178(73.5 \%)$ & $143(79.4 \%)$ & \multirow{2}{*}{$\begin{array}{c}0.161 \\
1.97\end{array}$} & \multirow{2}{*}{$\begin{array}{c}1.39 \\
0.877-2.203\end{array}$} \\
\hline $1 / 1$ & 64 (26.5\%) & 37 (20.6\%) & & \\
\hline
\end{tabular}

similar percentages of lymphocytes and macrophages, as well as similar percentages of lymphocyte subpopulations in BALF (Table V). There was only an insignificantly higher percentage of lymphocytes $\left(\chi^{2}=1.27 ; p=0.26\right)$ and CD8+ T lymphocytes $\left(\chi^{2}=2.26 ; p=0.133\right)$ in BALF of patients with ACE gene DD genotype (respectively: 40.4 $\pm 20.24 \%$ and $14.07 \pm 10.83 \%$ ) than in patients who were carriers of the I allele of the $A C E$ gene (respectively: $33.85 \pm 21.85 \%$ and $11.42 \pm 9.68 \%$ ).

\section{Discussion}

Sarcoidosis is probably caused by the influence of specific environmental factors on the immune system of genetically predisposed individuals. The problem of the relationship between the subjects' environment and incidence of sarcoidosis appeared in the literature back in the 1950s. The results of the first epidemiological studies pointed toward a significant correlation between the development of the disease and living in the country; however, the exact inciting exposure in a rural residence is unknown [22, 23]. Cummings et al. [24] made a detailed analysis of a large group of 1700 patients with clinically and histologically confirmed sarcoidosis (1949-1956). The assessment included factors such as age, race, gender, place and date of birth and place of residence. The most striking observation related to the geographical distribution of the patients. It was observed that sarcoidosis was more common in rural areas, particularly in communities where the inhabitants were employed in local wood factories, or worked at chopping wood. The timber industry is present in Lublin Voivodeship, but only 2 of the examined patients were employed there.

Conclusions of the multicenter ACCESS study conducted on a group of 718 patients with newly diagnosed sarcoidosis were similar: residence in an agricultural environment was recognized as a potential risk factor for the disease. The authors observed an elevated odds ratio $(O R=1.46 ; 95 \% \mathrm{Cl}=$
1.13-1.89) among individuals who worked in agriculture and who had lived in a small town ( $\leq 50000$ population) in childhood. In the pathogenesis of the disease, the effect of exposure to insecticides $(\mathrm{OR}=1.52 ; 95 \% \mathrm{Cl}=1.14-2.04)$, chemicals, mould and mildew $(\mathrm{OR}=1.61$; $95 \% \mathrm{Cl}=1.13-2.31)$ and contact with birds and farm animals were stressed [3]. Virtually every patient in the study group of rural residents has been in contact with a number of the above-mentioned exposures.

A different approach was taken in the study by Kreider et al. [25], in which the sarcoidosis cases were subdivided by clinical phenotype. Putting forward the hypothesis that different sarcoidosis phenotypes may be associated with different exposure risks, Kreider divided patients into a group with pulmonary-only disease (311 cases) and a group with systemic disease (407 cases). The study demonstrated that exposures to wood burning and agricultural organic dust are associated with risk of pulmonary sarcoidosis, in which disease is present only in the lungs. The authors' conclusion was that the differentiation of sarcoidosis subjects on the basis of clinical phenotypes suggests that these subgroups may have unique environmental exposure associations. The exposure to agricultural organic dusts and wood burning may not be causative in the development of the disease but rather may affect the clinical manifestations of the disease in a susceptible individual. However, our patients in groups differentiated by place of residence and thereby exposed to different air pollution showed no differences in disease phenotype.

We found no evidence that place of patients' residence influences the condition of the immunological system in the airways. It was demonstrated that the cellular response induced by $T$ lymphocytes is more intense in patients with acute clinical manifestations of sarcoidosis (Löfgren syndrome) and in patients with radiological stage I disease. A high percentage of lymphocytes 


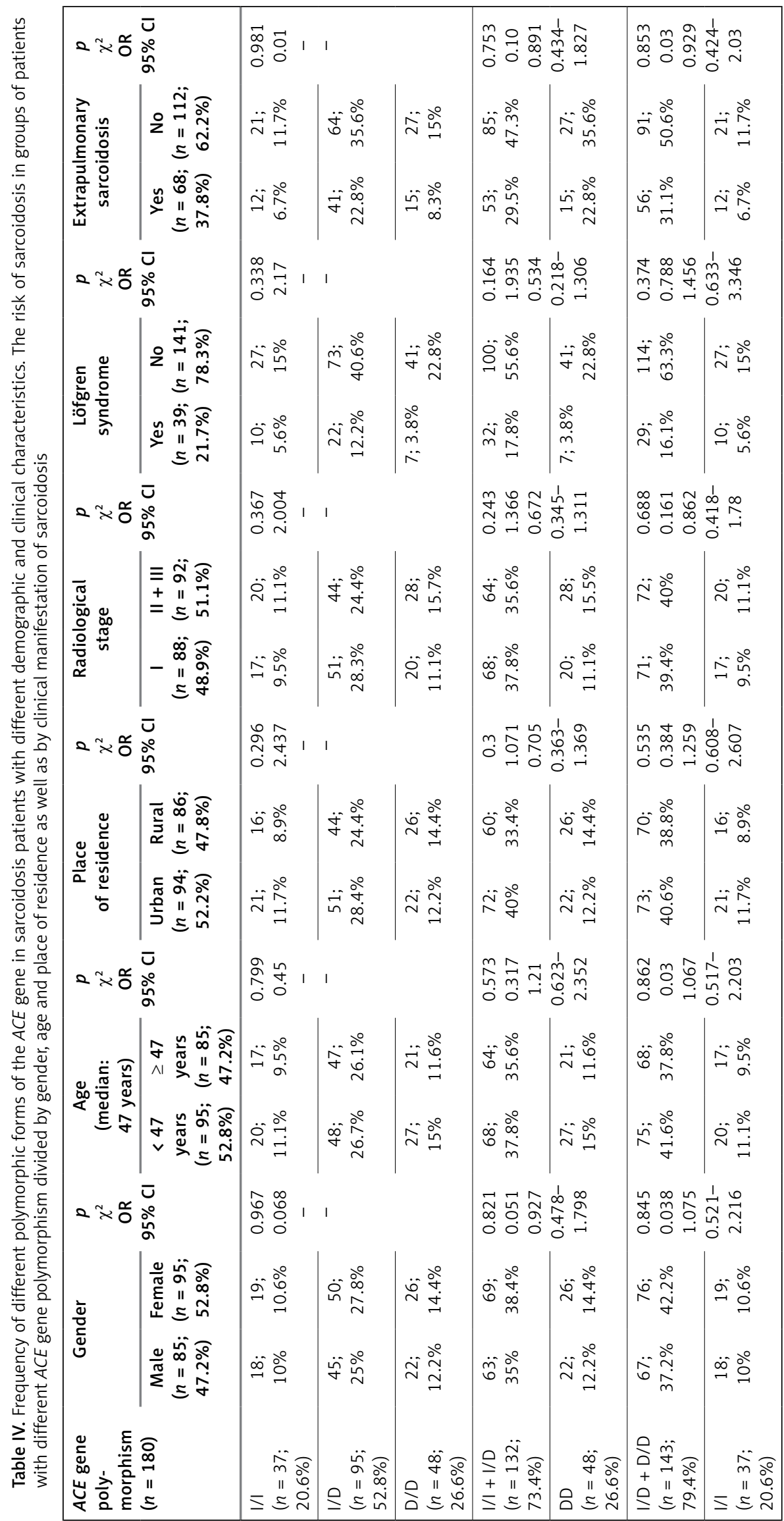


Table V. Percentage of leukocytes in BALF, depending on the polymorphism of the ACE gene in patients with sarcoidosis

\begin{tabular}{|c|c|c|c|c|}
\hline \multirow{2}{*}{$\begin{array}{l}\text { Subpopulations } \\
\text { of leukocytes in BALF } \\
\text { (median } \pm \text { SD) }\end{array}$} & \multicolumn{3}{|c|}{$A C E$ gene polymorphism } & \multirow{2}{*}{$\begin{array}{l}p \\
\chi^{2}\end{array}$} \\
\hline & I/I & I/D & $D / D$ & \\
\hline $\begin{array}{l}\text { Lymphocytes (\%) } \\
(36.85 \pm 21.25)\end{array}$ & $38.89 \pm 21.17$ & $31.92 \pm 21.65$ & $40.4 \pm 20.24$ & $\begin{array}{l}0.086 \\
4.912\end{array}$ \\
\hline $\begin{array}{l}\text { Macrophages (\%) } \\
(56.31 \pm 21.27)\end{array}$ & $52.72 \pm 21.55$ & $61.89 \pm 21.87$ & $52.9 \pm 19.7$ & $\begin{array}{l}0.366 \\
2.011\end{array}$ \\
\hline $\begin{array}{l}\text { T lymphocytes (\%) } \\
(90.17 \pm 8.82)\end{array}$ & $90.14 \pm 5.68$ & $90.12 \pm 10.3$ & $90.59 \pm 6.97$ & $\begin{array}{l}0.686 \\
0.754\end{array}$ \\
\hline $\begin{array}{l}\text { CD4+ Th lymphocytes (\%) } \\
(76.1 \pm 13.37)\end{array}$ & $78.12 \pm 10.92$ & $76.18 \pm 14.7$ & $74.1 \pm 11.76$ & $\begin{array}{c}0.527 \\
1.28\end{array}$ \\
\hline $\begin{array}{l}\text { CD8+ T lymphocytes (\%) } \\
(12.1 \pm 10.01)\end{array}$ & $10.2 \pm 8.82$ & $11.86 \pm 9.88$ & $14.07 \pm 10.83$ & $\begin{array}{c}0.407 \\
1.8\end{array}$ \\
\hline $\begin{array}{l}\text { B lymphocytes (\%) } \\
(1.01 \pm 1.16)\end{array}$ & $0.91 \pm 1.1$ & $1.01 \pm 1.25$ & $1.23 \pm 0.96$ & $\begin{array}{l}0.262 \\
2.679\end{array}$ \\
\hline $\begin{array}{l}\text { CD4 : CD8 Ratio } \\
(5.78 \pm 5.73)\end{array}$ & $7.53 \pm 4.83$ & $5.41 \pm 5.73$ & $5.29 \pm 6.32$ & $\begin{array}{l}0.834 \\
0.438\end{array}$ \\
\hline
\end{tabular}

in BALF as well as a high CD4:CD8 ratio is considered to be pathognomonic for respiratory sarcoidosis [26-28]. The literature presents a statistically significant correlation between the reduction in the percentage of CD4+ $T$ helper cells and the CD4 : CD8 ratio in the airways, and the appearance of lung fibrosis in higher radiological stages of sarcoidosis [29-31].

There are no data on the impact of genetic polymorphisms on the risk of development and the clinical course of sarcoidosis in patients living in different (rural and urban) environments. On the other hand, determining the relationship between polymorphism of the $A C E$ gene and sarcoidosis has been the subject of many studies $[32,33]$. In our study, we found no difference in the incidence of different genotypes and alleles of the ACE gene in patients with sarcoidosis divided by gender, age and place of residence. Thus, ACE gene polymorphism was not a factor differentiating urban and rural residents in terms of predisposition to sarcoidosis. Moreover, we found no relationship between gene polymorphism and clinical manifestation of sarcoidosis. Therefore, we formed a hypothesis that there is no association between $A C E$ gene polymorphism and the risk of development or clinical course of sarcoidosis in Polish patients, regardless of where they live.

McGrath et al. conducted a study in Caucasian patients from the Czech Republic and the UK [32]. The results did not confirm the effect of $A C E$ gene polymorphism on the risk of development and clinical course of the disease. Also, Sari et al. did not observe any significant differences between the controls and sarcoidosis patients with respect to genotype distribution and allele frequencies of the ACE gene in Turkish sarcoidosis patients and healthy individuals [33]. However, Yilmaz et al. an- alyzed a Turkish population and found that the $D$ allele was more frequent in the sarcoidosis patient group. No significant differences in frequencies of I/I, I/D, D/D genotypes were observed between the sarcoidosis and control groups. Similarly, frequencies of these genotypes showed no significant differences between sarcoidosis patients with and without extrapulmonary involvement [34]. These results are in concordance with our findings in a Polish population.

On the other hand, Salobir et al. [35] observed a higher incidence of DD homozygotes among sarcoidosis patients as compared to the control group ( $37 \%$ vs. $21 \%$ ), with insignificantly higher frequency of the $D$ allele. Effects of $A C E$ gene polymorphism on the course of sarcoidosis were observed within the African-American population, as presented by Maliarik et al. [36]. In a study that compared the role of $A C E$ gene polymorphism in the development of the disease among Caucasians and African Americans, only in the African American group was the incidence of sarcoidosis significantly higher in the DD homozygotes. The impact of gene polymorphisms on the course of disease was not confirmed, but it was stressed that the risk of disease progression may be higher in patients with genotype II. Another recent meta-analysis of the ACE I/D polymorphism, which was based on a total sample of 1556 patients and 2381 controls, demonstrated that the DD genotype of the $A C E$ gene is associated with susceptibility to sarcoidosis in Europeans and East Asians [37].

In the past 20 years of development, differences between the country and the city in Poland have been significantly reduced. This process took place through the reform of local government, education, the use of EU funds. There have been profound changes in agriculture. Modernized food 
production technologies changed the economic activity of the rural population. The Polish Main Statistical Office shows that in 2008, $43 \%$ of the rural population aged 15 and over was associated with farming. Compared to previous years, the proportion of people associated with agriculture has a tendency to decrease. These changes result in reduction of the polarization of exposure to different biological and chemical factors in people living in urban and rural environments, which may be the cause of the lack of differences in the clinical and immunological picture of sarcoidosis in urban and rural areas of Lublin Voivodeship [38].

In conclusion, our results do not support the previous concept which suggested a higher incidence of sarcoidosis in individuals living in rural areas. We found no differences in the clinical course of sarcoidosis in patients living in rural and urban environments. No correlations between $A C E$ gene polymorphism and development of sarcoidosis in patients divided by gender, age and place of residence as well as by clinical manifestation of sarcoidosis were found. The reason for this could be the fact that the studied population consisted of people employed in agriculture, but with no particular distinction of professions identified in the above-mentioned papers as being at high risk for occurrence of sarcoidosis, for example employees of the wood industry. It is also possible that this is related to the changing environment of rural areas, increasing urbanization and pollution, and the changing way of life of people living in rural areas.

\section{Conflict of interest}

The authors declare no conflict of interest.

\section{References}

1. Rybicki BA, Iannuzzi MC. Epidemiology of sarcoidosis: recent advances and future prospects. Semin Respir Crit Care Med 2007; 28: 22-35.

2. Sharma OP. Sarcoidosis around the world. Clin Chest Med 2008; 29: 357-63.

3. Newman LS, Rose CS, Bresnitz EA, et al. A case control etiologic study of sarcoidosis: environmental and occupational risk factors. Am J Respir Crit Care Med 2004; 170: 1324-30.

4. Ding Q, Cao C, Chen Z, Tabusi M, Chen L, Deng Z. A functional EGF+61 polymorphism is associated with severity of obstructive sleep apnea. Sleep Breath 2014; DO 10.1007/s11325-014-1035-4.

5. Wu Y, Cao C, Wu Y, et al. TNF-alpha-308G/A Polymorphism contributes to obstructive sleep apnea syndrome risk: evidence based on 10 case-control studies. PLoS One 2014; 9: e106183.

6. Foley PJ, Lympany PA, Puscinska E, Zielinski J, Welsh KI, $\mathrm{du}$ Bois RM. Analysis of MHC encoded antygen - processing genes TAP1 and TAP2 polymorphisms in sarcoidosis. Am J Rep Crit Care Med 1999; 160: 1009-14.

7. Hizawa N, Yamaguchi E, Furuya K, Jinushi E, Ito A, Kawakami Y. The role of the C-C chemokine receptor 2 gene polymorphism V64I (CCR2-64I) in sarcoidosis in a Japanese population. Am J Respir Crit Care Med 1999; 159: 2021-3.

8. Kieszko R, Krawczyk P, Chocholska S, Dmoszyńska A, Milanowski J. TNF-alpha and TNF-beta gene polymorphisms in Polish patients with sarcoidosis. Connection with the susceptibility and prognosis. Sarcoidosis Vasc Diffuse Lung Dis 2010; 27: 131-7.

9. Kurowski M, Majkowska-Wojciechowska B, Wardzyńska A, Kowalski ML. Associations of allergic sensitization and clinical phenotypes with innate immune response genes polymorphisms are modified by house dust mite allergen exposure. Arch Med Sci 2011; 7: 1029-36.

10. Coates $D$. The angiotensin converting enzyme (ACE). Int J Biochem Cell Biol 2003; 35: 769-73.

11. Bryant JW, Shariat-Madar Z. Human plasma kallikrein-kinin system: physiological and biochemical parameters. Cardiovasc Hematol Agents Med Chem 2009; 7: 234-50.

12. Miura K, Takahashi K, Fukuchi Y. Role of biochemical markers in sarcoidosis. Nihon Rinsho 2002; 60: 1741-6.

13. Rigat B, Hubert C, Alhenc-Gelas F, Cambien F, Corvol P, Soubrier F. An insertion/deletion polymorphism in the angiotensin I-converting enzyme gene accounting for half the variance of serum enzyme levels. J Clin Invest 1990; 86: 1343-6.

14. Danser AH, Schalekamp MA, Bax WA, et al. Angiotensin-converting enzyme in the human heart. Effect of the deletion/insertion polymorphism. Circulation 1995; 92: 1387-8.

15. Costerousse O, Allegrini J, Lopez M, Alhenc-Gelas F. Angiotensin I-converting enzyme in human circulating mononuclear cells: genetic polymorphism of expression in T-lymphocytes. Biochem J 1993; 290: 33-40.

16. Sekhri V, Sanal S, DeLorenzo LJ, Aronow WS, Maguire GP. Cardiac sarcoidosis: a comprehensive review. Arch Med Sci 2011; 7: 546-54.

17. Solecki L. Skażenie środowiska pracy i bytowania w rolnictwie [Polish]. IMW, Lublin 2005.

18. Nazimek L, Solecki T. Chemiczne zagrożenia w rolnictwie - stan aktualny i perspektywy [Polish]. IMW, Lublin 2006.

19. GUS. Portal informacyjny. Access: 07.12.2014. Available at: http://stat.gov.pl/

20. Główny inspektorat ochrony środowiska. Stan środowiska w województwie lubelskim. Access 07.12.2014. Available at: http://www.gios.gov.pl/

21. Camós S, Cruz MJ, Morell F, Solé E. Genetic-based reference values for angiotensin-converting enzyme (ACE) according to I/D polymorphism in a Spanish population sample. Clin Chem Lab Med 2012; 50: 1749-53.

22. Gentry JT, Nitowsky HM, Michael MJ. Studies on the epidemiology of sarcoidosis in the United States: the relationship to soil areas and to urban-rural residence. J Clin Invest 1955; 34: 1839-56.

23. Douglas AC. Sarcoidosis in Scotland. Am Rev Respir Dis 1961; 84: 143-7.

24. Cummings MM, Dunner E, Williams JH Jr. Epidemiologic and clinical observations in sarcoidosis. Ann Intern Med 1959; 50: 879-90.

25. Kreider ME, Christie JD, Thompson B, et al. Environmental exposures and the clinical phenotype of sarcoidosis. Chest 2005; 128: 207-15.

26. Costabel U, Bross KJ, Guzman J, Nilles A, Ruhle KH, Matthys $H$. Predictive value of bronchoalveolar $T$ cell subsets for the course of pulmonary sarcoidosis. Ann NY Acad Sci 1986; 465: 418-26.

27. Drent M, Wagenaar SS, Mulder PH, Van Velzen-Blad H, Diamant M, Van den Bosch JM. Bronchoalveolar lavage 
fluid profiles in sarcoidosis, tuberculosis, and non-Hodgkin's and Hodgkin's disease. An evaluation of differences. Chest 1994; 105: 514-9.

28. Ward K, O'Connor C, Odlum C, Fitzgerald MX. Prognostic value of bronchoalveolar lavage in sarcoidosis: the critical influence of disease presentation. Thorax 1989; 44: 6-12.

29. Danila E, Jurgauskiene L, Malickaite R. BAL fluid cells and pulmonary function in different radiographic stages of newly diagnosed sarcoidosis. Adv Med Sci 2008; 53: 228-33.

30. Verstraeten A, Demedts M, Verwilghen J, et al. Predictive value of bronchoalveolar lavage in pulmonary sarcoidosis. Chest 1990; 98: 560-7.

31. Drent M, van Velzen-Blad H, Diamant M, Hoogsteden HC, van den Bosch JM. Relationship between presentation of sarcoidosis and $T$ lymphocyte profile. A study in bronchoalveolar lavage fluid. Chest 1993; 104: 795-800.

32. McGrath DS, Foley PJ, Petrek M, et al. Ace gene I/D polymorphism and sarcoidosis pulmonary disease severity. Am J Respir Crit Care Med 2001; 164: 197-201.

33. Sarı G, Kurt E, Saydam F, Değirmenci I, Güneş HV. Association between I/D polymorphism in the ACE gene and sarcoidosis in Turkish patients. Cytotechnology 2014; 10: DOI:10.1007/s10616-014-9747-7.

34. Yılmaz D, Karkucak M, Coşkun F, Yakut T, Uzaslan EK. ACE gene I/D polymorphism and risk of sarcoidosis development in Turkish patients. Tuberk Toraks 2012; 60: 201-6.

35. Salobir B, Medica I, Tercelj M, Kastrin A, Sabovic M, Peterlin B. Association of angiotensin-converting enzyme/ DD genotype with sarcoidosis susceptibility in Slovenian patients. Med Sci Monit 2007; 13: 538-42.

36. Maliarik MJ, Rybicki BA, Malvitz E, et al. Angiotensinconverting enzyme gene polymorphism and risk of sarcoidosis. Am J Respir Crit Care Med 1998; 158: 1566-70.

37. Song GG, Kim JH, Lee YH. Associations between the angiotensin converting enzyme insertion/deletion polymorphism and susceptibility to sarcoidosis: a meta-analysis. J Renin Angiotensin Aldosterone Syst 2013: DOI:10.1177/1470320313489059

38. Rakowska J, Wojewódzka-Wiewiórska A. Zróżnicowanie przestrzenne obszarów wiejskich w Polsce - stan i perspektywy rozwojuw kontekście powiązań funkcjonalnych. Ekspertyza wykonana na zamówienie Ministerstwa Rozwoju Regionalnego [Polish]. Warsaw 2010. 